\title{
Research on Teaching Reform of Engineering Management Major in Higher Vocational Colleges Based on BIM Technology
}

\author{
Ping Liu \\ Liaoningjianzhu Vocational College, Liaoning, Liaoyang, 111000
}

Keywords: BIM technology; higher vocational colleges; engineering management; teaching reform

\begin{abstract}
Nowadays, the overall development trend of China's construction industry tends to BIM technology. As an application-oriented talent college, higher vocational colleges carry out engineering management reform based on BIM technology, which has important practical significance. The paper outlines the status quo, highlighting problems and importance of the teaching reform of engineering management majors in higher vocational colleges based on BIM technology. It mainly analyzes the practical application of BIM technology in the teaching reform of engineering management majors in higher vocational colleges, high-tech talents with social needs and their development trends.
\end{abstract}

\section{Introduction}

The building information model, BIM, is widely used in the construction engineering industry; the tools that the building information model relies on in actual operation management, construction, project design and optimization are all provided by BIM technology [1]. In recent years, with the continuous upgrading and development of BIM technology, most vocational colleges in China carry out engineering management reform based on BIM technology; the development of BIM teaching in China is relatively slow compared with foreign countries, and BIM technology can be used in higher vocational colleges. The management professional teaching reform plays an important role. Therefore, under the background of the whole society paying attention to the construction quality of construction engineering, it is of great research value to apply BIM technology to the teaching reform of engineering management major in higher vocational colleges.

\section{The Current Situation of Teaching Reform of Engineering Management Major in Higher Vocational Colleges Based On BIM Technology}

In recent years, with the rapid development of China's society and the acceleration of urbanization, I have been increasing the demand for BIM professional and technical personnel in construction engineering enterprises. However, the current number of BIM professional and technical personnel in China cannot meet the market demand. Although most of the engineering management majors in higher vocational colleges have already opened the building information model professional technical courses, the BIM professional technical courses are in the initial stage, and the curriculum system is not mature. And in the vocational colleges that offer BIM professional technology courses, many schools take BIM professional and technical courses as elective courses [2], and lack of understanding of BIM professional and technical values. The problems facing the teaching of BIM technology courses in engineering management majors in higher vocational colleges in China can be summarized as follows:

First, the current BIM technology courses offered by engineering management majors in higher vocational colleges tend to cause students to pay too much attention to the use of BIM software or to pay attention to the application of BIM technology in the course of teaching, ignoring the BIM technology in the entire construction project. Second, the BIM technology courses offered by the engineering management majors of higher vocational colleges have not formed a close relationship with other courses, which leads to obstacles in actual training, which makes the practical value of BIM technology not fully exerted. Third, the BIM technical courses offered by the engineering 
management majors of higher vocational colleges usually use simple cases in engineering as teaching cases. The difficulty of curriculum design fails to meet the difficulty of actual construction projects, resulting in the BIM technical level of students staying and the beginner stage, BIM Technical practice is poor. Fourth, most vocational colleges only regard BIM technology courses as elective courses for engineering management majors, attach importance to theoretical teaching and neglect practical training, and the teaching resources of professional teachers resources, training bases and training equipment of BIM technology courses are serious. Fifth, the BIM technology course offered by the engineering management major of higher vocational colleges has a complicated knowledge system; the professional BIM technology course fails to set the teaching objectives uniformly, which leads to the failure of the higher vocational colleges in China to unify the teaching standards of BIM technology courses. In turn, the teaching efficiency of BIM technology courses is reduced.

\section{The Importance of Teaching Reform of Engineering Management Major in Higher Vocational Colleges Based On BIM Technology}

BIM technology has been fully promoted in construction engineering enterprises, and the Chinese government has also issued policies related to BIM technology [3]; most construction projects have applied BIM technology to supervise and manage the entire construction process, including the design before the construction, Construction, operation and maintenance, etc.; but the current number and professionalism of BIM professional and technical personnel can not meet the market demand. Therefore, as a vocational college that trains technical application talents, it should keep up with the times, open BIM technology courses in engineering management, and strengthen the training of BIM technical talents to meet the current market demand and the future development trend of BIM technology.

\section{Application of Teaching Reform of Engineering Management Major in Higher Vocational Colleges Based on BIM Technology}

According to the BIM technology of higher vocational colleges, the teaching reform of engineering management majors, according to the academic research results and practical experience, analyzes the application scope of BIM technology in the teaching reform of engineering management majors in higher vocational colleges, including: higher vocational colleges The engineering management professional teaching system is built in the target, the engineering management professional course system setting in higher vocational colleges, the construction of the engineering management professional course training base in higher vocational colleges, the teaching resources and teaching methods of engineering management majors in higher vocational colleges, and the higher vocational colleges.

\subsection{Application Based on the Construction of BIM Teaching System and the Application of Goals.}

As we all know, the development of BIM technology in China is in its infancy, and the training methods and objectives of BIM technology professionals are relatively immature. If relevant departments invest heavily in the engineering management majors of higher vocational colleges to open BIM technology courses, it will lead to the change of teaching in higher vocational colleges. Focus on the original teaching curriculum. Therefore, higher vocational colleges can carry out engineering management professional teaching reform based on BIM technology according to actual conditions.

The construction of the BIM technology teaching system is to let students understand the development process of BIM technology and future trends and concepts, so that students can recognize the value of BIM technology from the consciousness, so as to improve the initiative and enthusiasm of students to learn BIM technology. Exceptionally, after the BIM technology course is offered in the engineering management major of higher vocational colleges, it is necessary to 
continuously explore and improve the BIM technology teaching mode in the process of teaching, to help students master the theoretical knowledge of BIM technology and improve their practical operation ability, and to guarantee BIM professional technology. People can better adapt to the current social requirements, and then achieve the teaching objectives of the BIM technology curriculum.

\subsection{Application Based on BIM Curriculum System Setting.}

Higher vocational colleges apply the BIM curriculum to the previous curriculum system of engineering management after the BIM teaching system and goals are formulated according to the market demand for BIM professional and technical talents. According to the actual investigation, the engineering management professional courses of higher vocational colleges are adjusted in combination with BIM.

BIM technology can be well applied to the curriculum reform of higher vocational colleges. The effect of adjusting its curriculum is extremely beneficial to students and teaching. For example, first of all, the application of BIM technology teaching can present the traditional theoretical knowledge and construction cases directly to the students, so that students can be integrated into the actual construction project construction site to improve students' interest in learning. Secondly, let students master the application of BIM technology, and solve problems in actual construction projects, and take timely and effective solutions to improve work efficiency. Finally, students can embody the traditional abstract knowledge through the BIM technology course, and have a deep understanding of the internal relationship between construction project design, construction schedule, project cost, construction safety management and construction quality, and emphasize to the students.

\subsection{Application Based on the Construction of BIM Training Base.}

For the BIM technology with strong practicality, in the teaching process, teachers need to pay attention to practical teaching; vocational colleges apply BIM construction training base. At present, only a small number of higher vocational colleges in China have established BIM training bases, which fails to meet the initial requirements for training BIM technology-based application talents. Higher vocational colleges can establish their own BIM training bases based on the experience of other schools in building BIM training bases. For example, schools can cooperate with construction engineering companies or live with BIM software companies to enable students to master 3D measurement technology and physical construction. Basic skills such as mold, construction scheme design and schedule management [4]; further enhance students' practical application ability of BIM technology and comprehensively improve students' comprehensive ability of BIM.

\subsection{Application Based on BIM Teacher Resources and Teaching Methods.}

Applying BIM technology to the curriculum of engineering management majors in higher vocational colleges, the corresponding teacher resources and teaching methods should also be improved in time. 1. Can cooperate with BIM software company to carry out teaching materials and teacher professional skills training, and enhance the basic teaching ability of teachers BIM; 2 . Schools can consult with domestic construction enterprises, learn BIM technology, and train teachers' comprehensive ability; A BIM teacher team can be set up to allow the team to participate in various BIM technical conferences, expand the vision of teachers, master the latest BIM technology and knowledge; use the latest teaching methods for teaching; 4. Higher vocational colleges can also hire BIM professional technology according to the school conditions. As a part-time teacher, students can be exposed to the practical application of BIM technology.

\subsection{Application Based on BIM Skills Competition.}

In order to achieve the training goal of BIM high-tech application talents, China's higher vocational colleges can apply BIM to relevant skill competitions. For example, a small BIM skill competition will be held in the school, and BIM technical training will be given to the students before the competition, so that students can fully utilize the BIM ability in the skill competition. Encourage and further guide the training of students who have achieved poor results, reward 
students who have achieved good results, and invite BIM professional and technical personnel to train them to be representatives of the school and participate in the "Swell Cup" held by the national universities. "BIM Modeling Contest; on the basis of the awards, further participate in the BIM contests such as "Eibi Cup", "Dragon Cup", "Guang Lianda" and "Innovation Cup". By participating in the BIM Skills Competition, students will have a deeper interest in learning BIM technology. In this way, students not only actively learn BIM technology, but also strengthen the teamwork ability and professional practical application skills that should be in BIM technology to improve students' comprehensive ability of BIM. They can also help teachers to clarify teaching objectives and improve teachers' BIM technical practice ability.

\section{Conclusion}

In summary, BIM technology has a wide range of applications in the teaching reform of engineering management in higher vocational colleges. At present, BIM technology is still developing in the development. For the engineering management majors of higher vocational colleges in China, the application of BIM technology is in its infancy [5], and the demand for talents who can master and apply BIM technology is increasing. And the future development trend of the construction engineering industry is BIM technology. Therefore, in order to cultivate high-tech applied talents that meet the needs of the current society and the future development trend of construction projects, and promote the development of construction engineering, China's higher vocational colleges need to keep up with the times and use BIM technology as the main course of engineering management.

\section{References}

[1] Zhao Di. Research on the Teaching Management of Higher Vocational Construction Engineering Based on BIM Technology [J].Shaanxi Education (High Education), 2018, 05(157):60.

[2] Wang Xin,Wang Peng.The Construction of BIM Professional Ability in Civil Engineering Majors in Higher Vocational Colleges[J].Journal of Yangzhou College of Education,2018,01(36):81.

[3] Yang Huifen. Exploration of Teaching Reform of Engineering Management Major in Higher Vocational Colleges Based on BIM Technology [J].Knowledge Economy, 2017, 23(081):141.

[4] Feng Gairong. Research on Teaching Reform of Construction Engineering Management Course System Based on BIM Technology [J]. Building Materials and Decoration, 2018, 05(132):162.

[5] Zhao Liheng, Liu Jie, Zhang Jianfeng. Research on BIM Technology in the Teaching of Construction Technology Courses [J]. Heilongjiang Science, 2018, 04 (09): 158. 